\title{
Sizing and Siting fuel cell systems using forest residues
}

\author{
M. Gómez ${ }^{1}$, and F. Jurado ${ }^{2}$ \\ ${ }^{1}$ Unidad Territorial de Empleo y Desarrollo Tecnológico "Sierra de Cazorla", Junta of Andalusia \\ 23470 Maestro Francisco Yuste, no 2, Cazorla (Jaén), Spain \\ Phone: +34 953 720795, e-mail: manuel.gomez.gonzalez@gmail.com \\ ${ }^{2}$ University of Jaén, Department of Electrical Engineering \\ 23700 Alfonso X, $n^{\circ} 28$, EPS Linares (Jaén), Spain \\ Phone: +34953 648518, e-mail: fjurado@ujaen.es
}

\begin{abstract}
This paper presents the characteristics of utilization of forest residues in solid oxide fuel cell hybrid systems. A method is proposed to evaluate the profitability of these systems taking into account the point of view of the investor. On the other hand, and from the point of view of the electric distribution company, an algorithm is suggested to reduce power losses in distribution networks and purchased energy costs.
\end{abstract}

\section{Key words}

Distributed generation, forest residues, fuel cell, power losses.

\section{Introduction}

The Kyoto Protocol, approved in 1997, obliges countries to reduce greenhouse gas emissions. For the European Union the commitment is to reduce to $8 \%$ by the year 2010 . The goal is to increase the contribution of renewable energy sources to 12 $\%$ of the total energy supplied by 2010. The Directive 2001/77/CE, forces member countries to adopt measures for production growth of electric power with renewable sources. Also, it noted that the main contribution for this execution could come from the biomass [1], [2].

Electricity production with renewable energies is completely linked with the distributed power generation that carries numerous benefits for the distribution network.

The main advantage of biomass based power generation is that the cycle of growth and combustion of the biomass has a net zero level of $\mathrm{CO}_{2}$ production. Also, the use of biomass generates employment and rural economic development, where it takes place, contributing to sustainability. Nevertheless, and due to their particularities, it becomes necessary to prove that power generation from biomass is both technically and economically viable.

For the optimal determination of sizing and location of the generation system in distribution network, it is necessary to minimize a function of costs. This function is composed for the sum of costs more important: the costs of energy losses and the costs of purchased energy.

This paper proposes a method for determining the optimal sizing and placement of solid oxide fuel cell (SOFC) system taking into account:

- Profitability analysis of SOFC plant with forest residues as fuel (investor's standpoint).

- Minimizing power losses in distribution network and costs purchased energy (electric distribution company standpoint).

\section{Distributed Generation}

The history of electric power generation systems has been derived from large central station plants due to the economics of scale. Fossil fuel plants have represented the majority of this power generation. According to tradition, there was strong yearly demand growth, which was stable at around 6-7\%. Environmental issues and the oil crisis began to introduce new problems for the power industry in the 1970s. By the 1980s, these factors and changes in the economy had led to much smaller demand growth of around 1.6-3\%. Simultaneously, transmission and distribution (T\&D) costs have grown from a historical level of $25 \%$ to around $150 \%$ of generation costs. T\&D costs now represent almost two thirds of the capital expenditure budget for the utility industry. Thus, as a result of the reduced demand growth, increased T\&D costs, intensified environmental concerns and various regulatory and technological changes, large central station plants are often impractical. The utility industry's generation paradigm is shifting from economies of scale to something that has been coined economies of mass production [3].

The distributed generation (DG) is the generation of electricity by facilities sufficiently smaller than central generating plants as to allow interconnection at nearly any point in a power system. DG is not centrally planned, not centrally dispatched, usually connected to the distribution network and smaller than 50-100 MW [4].

DG options can be renewable sources such as photovoltaic systems, high temperature thermal solar system, wind turbines, mini-hydraulics and biomass. This definition also comprises the conventional small generators, internal 
combustion engines, fuel cells and micro-turbines.

The major technical advantages of DG are the following:

- Reduced losses in the distribution network.

- Improved voltage levels.

- Reduced atmospheric contamination.

- High efficiency.

- Increased system reliability and security.

- Improved power quality.

- Increased distribution network capacity.

The economic benefits basically are:

- Reduced investments.

- Reduced operation and maintenance costs.

- Increased productivity.

- Reduced fuel costs due to increased overall efficiency.

- Increased security for critical loads [5]-[7].

\section{Forest Residues}

Biomass is the organic matter of biological origin usable for other goals different to the alimentary (energetic, industrial, etc). It constitutes a renewable resource; their main components are carbon, oxygen, hydrogen and nitrogen.

The forest residues constitute a form of biomass. They are not habitually convertible in by-products. However, they can be used as organic fuel. They are obtained of the following operations previously planned:

- Forestry operations for enhancement of the forest mass (timber harvesting operations).

- Cull trees from thinnings and final fellings.

- Fire prevention tasks (surface mount cleaning, firebreaks, bushes cleaning, etc).

The governments regulate the types of works to develop every year in determined areas according to the vegetation density, type of species, age, diameter, etc. After treatments the dispersed residues are generated. Later, residues are piling and burning (what is applied currently). The near residues to forest tracks or roads can be piled by cavalry or skidders.

The residues are not incinerated, they are collected and transported to the generation plant for their energetic utilization; the works for biomass exploitation begin here, they would be integrated in the dimensioning and optimization of the electric generation. The previous doesn't suppose an increase of the cost, since the residues are not eliminated.

The forest residues are concentrated and transported beside the forest road. The main harvesting methods are:

- Extraction and chipping.

- Bundling at the roadside, transport and chipping at the power plant.

Bundling technology compresses the residues making highdensity bundles, it reduces the transport costs and minimizes its environmental impact. The bundling machine works at the roadside [8].

At the power plant, the residues are stored outdoors and before their use as fuel they are subjected to drying processes, chipping and milling. Later on, gasification and reforming process for the appropriate supply to generation system takes place.

The added advantages of the use would involve the reduction of plagues, smaller environmental impact and decrease in the possibilities of fires, etc.

Biomass exploitation depends on the following factors:

- Vegetation density.

- Type of species.

- Age of vegetation.

- Size of tops, needles, branches, etc.

- Forest surface treated annually according to Forest Plans.

- Accesses and average slope of the terrain.

The forest residues can be collected when the average slope is less than $50 \%$. Nevertheless, the major determinant is the terrain accessibility. The forest road density is directly related to the availability of forest residues. Considering that the biomass collection is economically feasible for a determined lateral distance to the forest roadside, the usable surface can be calculated by multiplying the forest road length by the lateral distance. Since these data are specific for each forest zone, they require a previous study.

\section{Gasification}

The options for conversion of biomass into electricity are combustion, gasification, integrated gasification combined cycle and pyrolysis. The biomass can be converted into producer gas by gasification (partial combustion) [9]. Biomass undergoes thermal decomposition at high temperatures (600$1000^{\circ} \mathrm{C}$ ) to form gaseous components like carbon monoxide and hydrogen as well as impurities such as particulates and tars. The biomass is generally treated prior to its introduction into the gasifier. This involves drying and proper sizing of the feedstock before feeding to the gasifier. The characteristic of the gas produced varies with the type of fuel material, gasifier and conditions. The product gas from the gasification process can be used (after cleaning and conditioning) in turbines, boilers and engines for the generation of heat and electricity and for the production of synthesis gases for the manufacture of fuels and chemicals, or hydrogen for fuel cells [10].

Gasifiers are classified as updraft or downdraft depending on the direction of flow of the biomass and the producer gas. In a downdraft gasifier the biomass and the gases flow are in the same direction (downwards). In a typical downdraft gasifier the biomass is fed from the top. It passes through the gasifier and undergoes the following sequence of processesdrying, pyrolysis, oxidation and reduction. The gas formed is passed through a cooling and cleaning subsystem that usually consists of a cyclone for particulate removal and a scrubber for cooling and cleaning the gas (removing the tar). Some ash is formed from the oxidation reactions. The ash moves through the reduction zone and gets removed from the ash disposal system (grate and ash collection system). The typical composition of producer gas is $20-22 \% \mathrm{CO}, 15-18 \% \mathrm{H}_{2}, 2-4 \%$ $\mathrm{CH}_{4}, 9-11 \% \mathrm{CO}_{2}$ and $50-53 \% \mathrm{~N}_{2}$ (by volume). This is a low calorific value fuel with a calorific value of 1000-1200 
$\mathrm{kcal} / \mathrm{Nm}^{3}[9]$.

\section{Fuel Cell System}

A fuel cell is an electrochemical device that converts chemical energy directly into electrical energy. It is based on the inverse reaction of the electrolysis $\left(\mathrm{H}_{2}+1 / 2 \mathrm{O}_{2} \rightarrow \mathrm{H}_{2} \mathrm{O}+\right.$ electrical energy). Different types of fuel cells exist with different performances and components. The classification is based on the electrolyte: proton exchange membrane fuel cell (PEMFC), phosphoric acid fuel cell (PAFC), molten carbonate fuel cell (MCFC), solid oxide fuel cell (SOFC), etc, [11].

The SOFC is composed of an electrolyte metallic oxide, no porous and good conductor. It can be manufactured in geometric different setups: planar, tubular, monolithic, etc. The SOFC is characterized fundamentally by their operating temperatures between $800{ }^{\circ} \mathrm{C}$ and $1000{ }^{\circ} \mathrm{C}$. These high temperatures simplify system configuration by permitting internal reforming, accepting their components determined gases that are very polluting for another type of fuel cells.

The operating high temperatures facilitate the development of cogeneration systems as well as hybrid power systems formed by the own fuel cell and gas turbine (GT). The thermal energy generated by electrochemical reactions in the fuel cell is utilized to produce more power output by a GT cycle. As a result, higher overall efficiency is expected (approximately $60 \%$ ) in comparison to that obtained from individual systems [11]-[13].

\section{Profitability Analysis}

\section{A. Technical dimensioning}

This study treats the feasibility of biomass energy systems, it is based on specific investment $I_{s}(€ / \mathrm{MW})$ and the correlation between the plant power $P_{e}(\mathrm{MW})$ and the net density of dry biomass yield, $d b$ (ton $/ \mathrm{km}^{2}$ yr d.m. dry mass), in a surface of production, $S\left(\mathrm{~km}^{2}\right)$, considering $S$ a circle with the centre situated in the power plant location and a radius $R$ (km), $S=\pi R^{2} \quad[14]$.

Therefore, given the lower heat value of the biomass, $H$ (MWh/ton), and the total mean efficiency of electric generation system, eff, the electricity produced, $E_{g}$, is equal to:

$$
E_{g}=S \cdot c p \cdot d b \cdot H \cdot e f f
$$

Where: $c p$ is a coefficient that is applied to take into account only the usable surface (areas near to the forest roads).

Presuming a plant running time of $T(\mathrm{~h} / \mathrm{yr})$, the electric power would be:

$$
P_{e}=\frac{S \cdot c p \cdot d b \cdot H \cdot e f f}{T}
$$

\section{B. Initial investment}

The initial investment (INV) for the design, construction of the generation plant and equipment necessary is expressed as:

$$
I N V=I_{s} \cdot P_{e}
$$

The governments of developed countries offer some support to the initial investment: incentives and low or interest-free loans. Only considering external financing and annual payments and not monthly, total payments for each year are:

$$
P A N=I N V \cdot(1-i n c) \cdot\left[\frac{i \cdot(1+i)^{N}}{(1+i)^{N}-1}\right]
$$

$N$ is the loan term in years. It is considered equal to the useful lifetime of the installation, $N=V_{u}$.

$i$ is the annual interest of the loan.

inc is the ratio between the granted incentives and the initial investment.

The present value of the initial investment from the user standpoint, $I N V_{U}$, is:

$$
I N V_{U}=P A N \cdot \frac{K_{i} \cdot\left(1-K_{i}^{V u}\right)}{1-K_{i}^{V u}}
$$

Where:

$K_{i}=1 /(1+d)$, being $d$ the nominal discount rate.

If the loan is not subscribed and the incentives are not received, that is to say, the investment is financed with own resources:

$$
I N V_{U}=I N V
$$

If the incentives are granted but the loan is not subscribed:

$$
I N V_{U}=I N V \cdot(1-i n c)
$$

With incentives and interest-free loans $(i=0)$ :

$$
I N V_{U}=I N V \cdot(1-i n c) \cdot \frac{K_{i} \cdot\left(1-K_{i}^{V u}\right)}{1-K_{i}^{V u}}
$$

\section{Cash inflows}

The present value of the cash inflows $\left(P V_{I N}\right)$ is the sum of the present value from incomes obtained during the useful lifetime, $V_{u}$, from the sold electric energy, it can be written as:

$$
P V_{I N}=p_{g} \cdot E_{g} \cdot \frac{K_{g} \cdot\left(1-K_{g}^{V u}\right)}{1-K_{g}^{V u}}
$$

Being:

$p_{g}$ is the selling price of the injected electric energy to the network (€/MWh).

$E_{g}$ sold and produced electric energy $(\mathrm{MWh} / \mathrm{yr})$.

$K_{g}=\left(1+r_{g}\right) /(1+d)$

$r_{g}$ the annual increase rate of the price of the sold energy. $d$ the nominal discount rate.

\section{Cash outflows}

The present value of the cash outflows $\left(P V_{\text {OUT }}\right)$ is the sum of costs on present value during the useful lifetime of the plant, $V_{u}$. They are considered, the annual collection costs, $C_{c}$, annual transport costs, $C_{t}$, annual maintenance costs, $C_{m}$, and annual operation costs, $C_{o}$.

The annual collection costs of biomass are:

$C_{c}=C_{c u} \cdot c p \cdot S \cdot d b$

Where $C_{c u}$ is the biomass collection unit cost (€/ton).

The annual transport costs of biomass are:

$$
C_{t}=C_{t u} \cdot c p \cdot S \cdot d b \cdot d_{a}
$$


Where: $d_{a}$ is the average distance $(\mathrm{km})$ of the plant to the load point. Accepting $S$ like a circle with the centre constituted by the power plant location, the average distance would be $d_{a}$ $=2 / 3 \cdot R \cdot c d$, being $c d \geq 1$ the ratio between the distance through forest roads and the radial distance from the load point and the plant.

$C_{t u}$ is the transport unit cost ( $€ /$ ton $\left.\mathrm{km}\right)$.

The annual maintenance costs are:

$C_{m}=m \cdot I N V$

$I N V$ is the total investment and $m$ is a coefficient.

The annual operation costs are written as:

$C_{o}=C_{o u} \cdot\left(N_{e}+2 \cdot P_{e}\right)$

$C_{o u}$ is the average unit cost for employment ( $€ /$ emp yr) and $N_{e}$ is the minimum number of necessary employments.

Finally, the present value of the cash outflows $\left(P V_{O U T}\right)$ is:

$$
\begin{aligned}
& P V_{O U T}=C_{c} \cdot \frac{K_{c} \cdot\left(1-K_{c}^{V u}\right)}{1-K_{c}^{V u}}+C_{t} \cdot \frac{K_{t} \cdot\left(1-K_{t}^{V u}\right)}{1-K_{t}^{V u}}+ \\
& +C_{m} \cdot \frac{K_{m} \cdot\left(1-K_{m}^{V u}\right)}{1-K_{m}^{V u}}+C_{o} \cdot \frac{K_{o} \cdot\left(1-K_{o}^{V u}\right)}{1-K_{o}^{V u}}
\end{aligned}
$$

Being:

$K_{c}=\left(1+r_{c}\right) /(1+d)$

$K_{t}=\left(1+r_{t}\right) /(1+d)$

$K_{m}=\left(1+r_{m}\right) /(1+d)$

$K_{o}=\left(1+r_{o}\right) /(1+d)$

Where:

$r_{c}=$ Annual increase rate of the biomass collection cost.

$r_{t}=$ Annual increase rate of the transport cost.

$r_{m}=$ Annual increase rate of the maintenance cost.

$r_{o}=$ Annual increase rate of the operation cost.

\section{E. Parameters related to the profitability analysis}

The present value $(P V)$ of an investment is the present value of the cash inflows minus the present value of the cash outflows during the useful lifetime of the plant, therefore:

$P V=P V_{I N}-P V_{\text {OUT }}$

The net present value (NPV) is the present value minus the present value of its investment:

$$
N P V=P V-I N V_{U}
$$

The profitability index $(P I)$ can be defined as the ratio between the net present value (NPV) of the project and the present value of the initial investment from the user standpoint, $I N V_{U}$ :

$$
\begin{aligned}
& P I=N P V / I N V_{U} \\
& P I=\left(P V / I N V_{U}\right)-1
\end{aligned}
$$

An investment is profitable when:

$$
N P V>0 \quad P I>0
$$

\section{Evaluation of the Placement and Sizing}

The proposed method is based, on the one hand, A) technical and economic analysis of plant to determine the minimum power system that provides profitability (investor's standpoint), on the other hand, B) find out the best placement and size to minimize energy losses and purchased energy cost in a given distribution network (point of view of electric distribution company).

For B), the algorithm proceeds as follows:

- Select a possible location of the plant.

- Calculate power flow and power loss.

- Calculate the energy losses and purchased energy costs.

- Rank location according to system costs.

- Return to the step 2 increasing proportionally the power of the plant on the same location until a penetration level determined.

- Repeat the process for others locations returning to the step 1 .

The results for each location and size of plant considered are valid if the range of the all buses voltage is acceptable.

\section{Calculation of Costs}

The energy losses and purchased energy costs are considered simultaneously. The Total Costs, $C_{T O T}$, is the sum of both.

\section{A. Cost of energy losses}

Electric power systems may suffer significant losses. The losses depend on the line resistance and currents and are usually referred to as thermal losses. While the line resistances are fixed, the currents are a complex function of the system topology and the location of the generation and load.

Consider the well known power flow equations with complex power $S_{i}=P_{i}+j Q_{i}$, injected at bus i as:

$$
\begin{aligned}
& P_{i}=V_{i} \sum_{j=1}^{n} Y_{i j} V_{j} \cos \left(\delta_{i}-\delta_{j}-\gamma_{i j}\right) \\
& Q_{i}=V_{i} \sum_{j=1}^{n} Y_{i j} V_{j} \sin \left(\delta_{i}-\delta_{j}-\gamma_{i j}\right)
\end{aligned}
$$

Where $Y_{i j}$ is the magnitude of the i-jth element of the bus admittance matrix, $V_{i}$ is the voltage magnitude at the ith bus, $\gamma_{i j}$ is the angle of the $\mathrm{i}$-jth element of the bus admittance matrix and $\delta_{i}$ is the phase angle of the voltage $V_{i}$.

In this paper, only the real power injections as they relate to electric losses are of concern. The system losses can be expressed as:

$$
P_{L}=\sum_{i=1}^{n} P_{G_{i}}-\sum_{i=1}^{n} P_{D_{i}}
$$

Where $P_{L}$ is the real power loss, $P_{G i}$ is the real power generated at the ith bus and $P_{D i}$ is the real power required at the ith bus [15].

Consider $C_{L U}$ the unitary cost of the energy loss ( $\left.€ / \mathrm{MWh}\right)$, the total energy losses cost $C_{L}$ is:

$$
C_{L}=C_{L U} \cdot P_{L} \quad(€ / \mathrm{h})
$$

\section{B. Cost of purchased energy}

In order to allow assessing the more convenient penetration level of DG in a given distribution network, the costs of purchasing energy from the grid $C_{T r}$ and from SOFC hybrid 
system, $C_{S}$, have been considered.

The global cost of purchased energy $C_{P E}$ is:

$$
C_{P E}=C_{T r}+C_{S} \quad(€ / \mathrm{h})
$$

\section{Results and Discussion}

TABLE I.- Standard values

\begin{tabular}{|l|l|}
\hline Parameters & Standard Values \\
\hline$d b$ (ton $/ \mathrm{km}^{2}$ yr d.m.) & 100 \\
\hline$H(\mathrm{MWh} /$ ton $)$ & 4 \\
\hline$c p$ & 0.25 \\
\hline$c d$ & 1.50 \\
\hline$C_{c u}(€ /$ ton $)$ & 40 \\
\hline$C_{t u}(€ /$ ton km) & 0.30 \\
\hline$C_{o u}(€ /$ emp yr) & 27000 \\
\hline$m$ & 0.03 \\
\hline$N_{e}($ mployments $)$ & 8 \\
\hline$e f f$ & 0.60 \\
\hline$T(\mathrm{~h} / \mathrm{yr})$ & 7500 \\
\hline$I_{s}(€ / \mathrm{MW})$ & 3500000 \\
\hline$V_{u}(\mathrm{yr})$ & 15 \\
\hline$p_{g}(€ / \mathrm{MWh})$ & 69 \\
\hline$i$ & 0.05 \\
\hline$d$ & 0.10 \\
\hline$r_{g}$ & 0.04 \\
\hline$r_{c}$ & 0.06 \\
\hline$r_{t}$ & 0.08 \\
\hline$r_{m}$ & 0.04 \\
\hline$r_{o}$ & 0.04 \\
\hline$i n c$ & 0.50 \\
\hline & \\
\hline & \\
\hline
\end{tabular}

Notes:

- The value of $p_{g}$ is currently unitary selling price of the electric energy injected to the network for these generation systems in Spain [16], [17].

- Interest bonus of the loan is not considered.

- The value of inc is currently applied for these systems in Andalusia, Spain [18].

\section{A. Investor's standpoint}

Fig. 1 and Fig. 2 show profitability index $(P I)$ as a function of the electric power $\left(P_{e}\right)$ of SOFC hybrid system and the radius $(R)$, respectively. The objective of investor is to maximize the profitability. The optimum electric power is $15.50 \mathrm{MW}$, to a radius of $22.70 \mathrm{~km}$.

$P I$ is more than 0 with $P_{e}>3 \mathrm{MW}, R>10 \mathrm{~km}$. Nevertheless, profitability is satisfactory to $4<P_{e}<60 \mathrm{MW}$.

Thus, for $R=15 \mathrm{~km}$ the installed electric power is of 6.80 MW. PI would be 0.2682 and NPV $2334000 €$. The surface to treat with a radius of $15 \mathrm{~km}$ is $706.86 \mathrm{~km}^{2}$ (70686 hectares). Annual works should be assured in the selected surface to get a successful project. This supposes an approximate production of 100 ton $/ \mathrm{km}^{2}$, therefore, the forest residues collected and exploited would be equal to 70686 ton/yr.

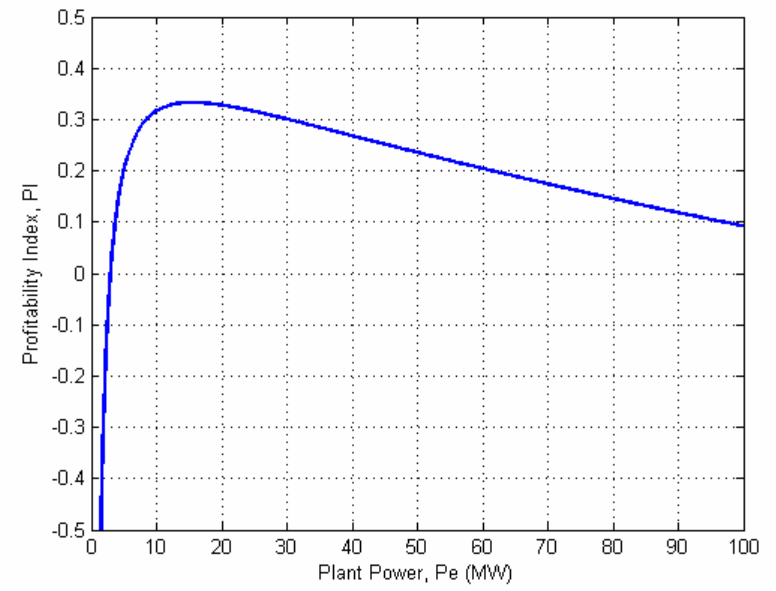

Fig. 1. Profitability index represented as a function of the plant electric power.

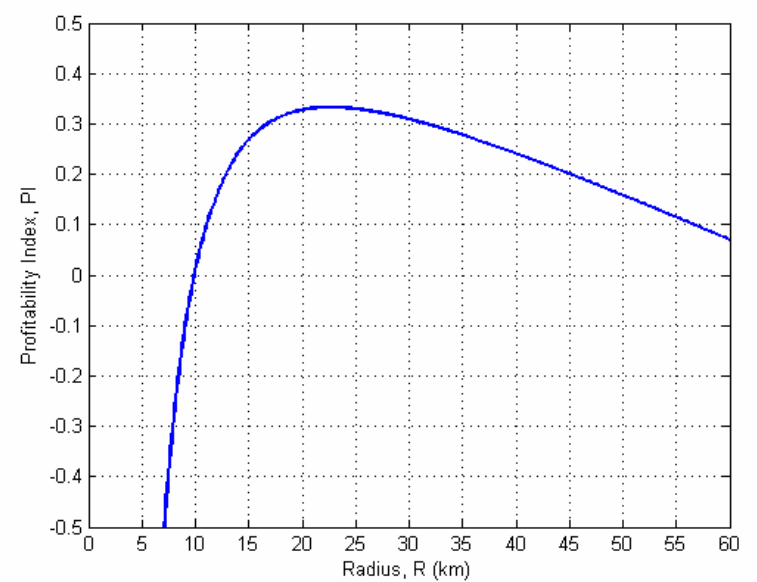

Fig. 2. Profitability index represented as a function of the radius.

\section{B. Electric distribution company standpoint}

A radial feeder with 11-bus, as shown in Appendix Fig A1, is applied to verify the method proposed. The simulated system is composed of uniformly distributed loads. The price of energy purchased from the wholesale electricity market is considered equal to $60 € / \mathrm{MWh}$, whereas the price of energy supplied by the SOFC system is equal to $69 € / \mathrm{MWh}$.

The total costs, given in Fig. 3, are calculated according to the algorithm presented in Section 7, considering different placement along the feeder and different size of the SOFC system.

Fig. 3 shows that the total cost is minimized $(530 € / \mathrm{h})$ at the bus 9 with an installed plant power of $4 \mathrm{MW}$ (penetration level of $50 \%$ ). Nevertheless, the global cost is reduced with electric powers between $1 \mathrm{MW}$ and $6 \mathrm{MW}$, at the buses 6 to the 11.The range of the all buses voltage is considered acceptable for $P_{e} \geq 2 \mathrm{MW}$.

Figs. 4 to 10 , display the total costs with different sizes (between $1 \mathrm{MW}$ and $8 \mathrm{MW}$ ) at the buses 5, 6, 7, 8, 9, 10 and 11 , respectively.

Therefore, taking into account both standpoints, in this case, the electric power of the SOFC hybrid system would be between $4 \mathrm{MW}$ and $6 \mathrm{MW}$, and located around the bus 9 
(between the 6 and the 11 bus).

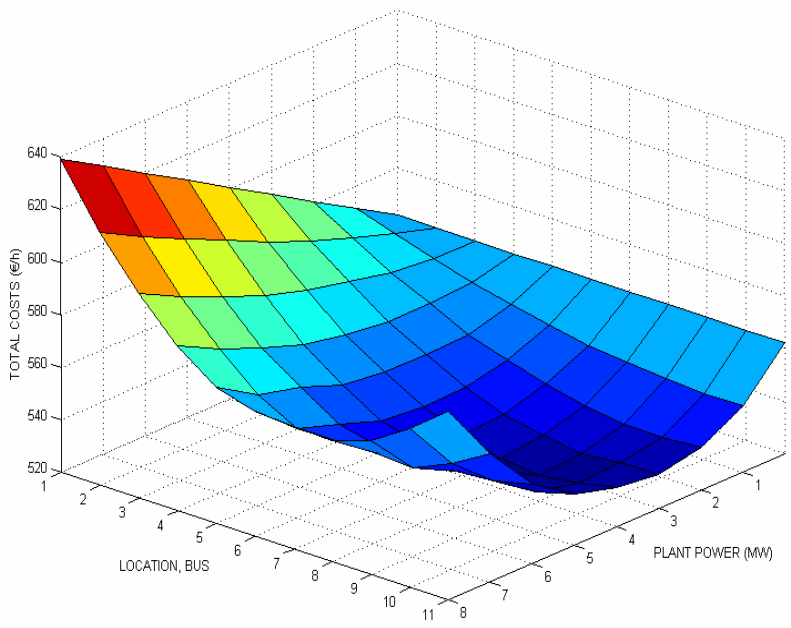

Fig. 3. Total costs in respect of SOFC system each size and location.

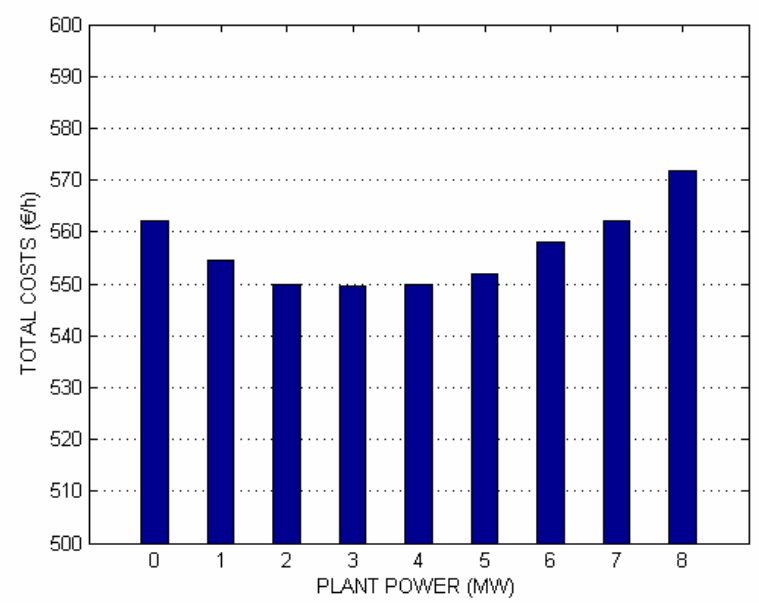

Fig. 4. Total costs. Generation system located at the BUS 5.

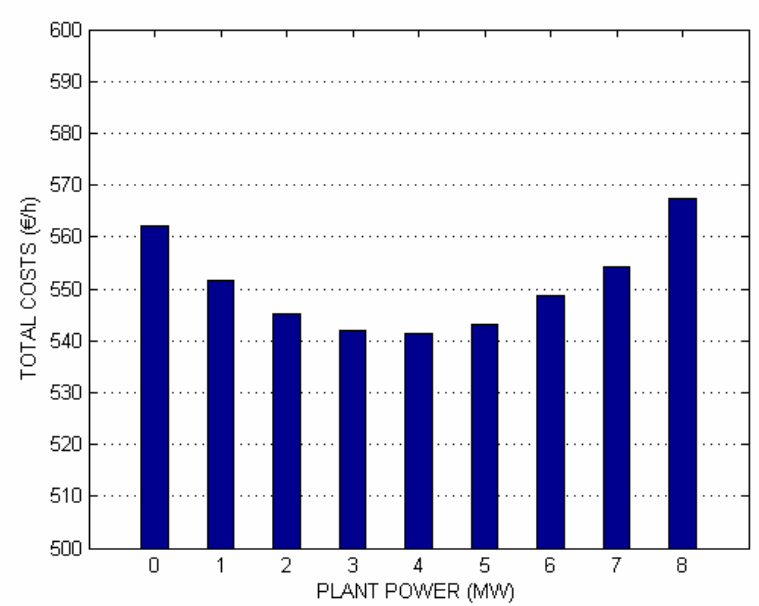

Fig. 5. Total costs. Generation system located at the BUS 6 .

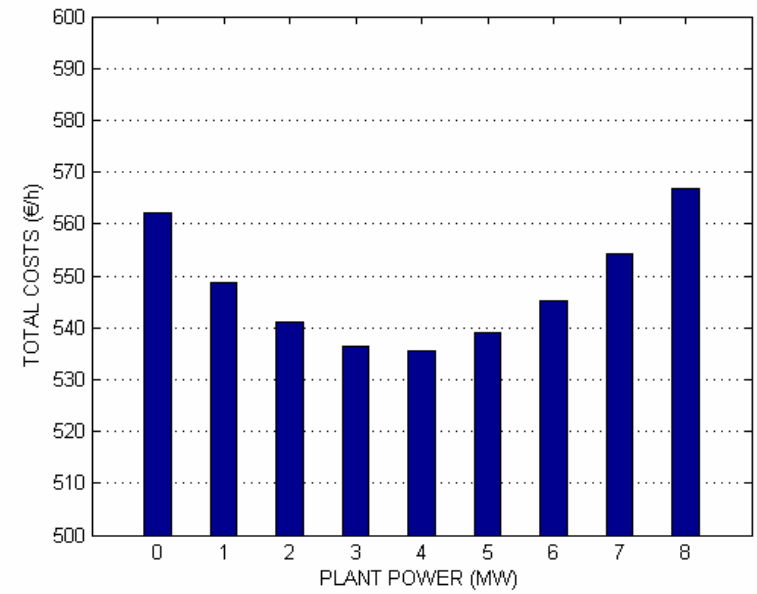

Fig. 6. Total costs. Generation system located at the BUS 7.

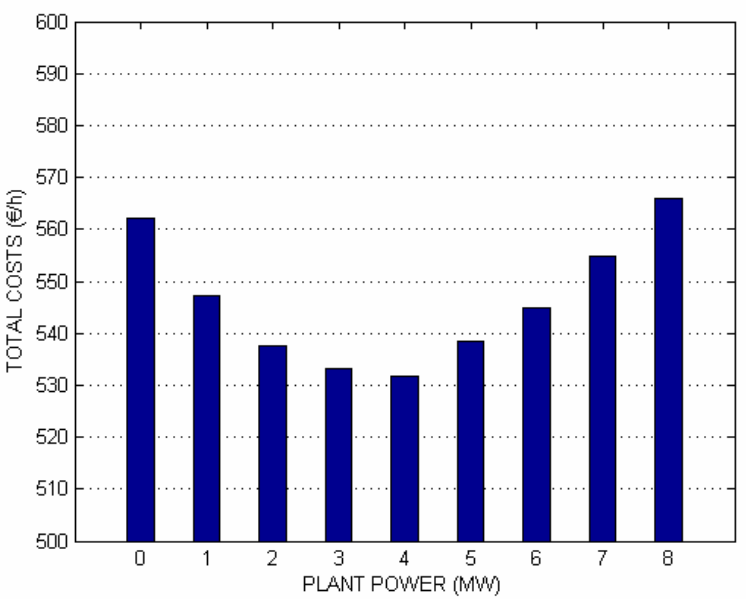

Fig. 7. Total Costs. Generation system located at the BUS 8 .

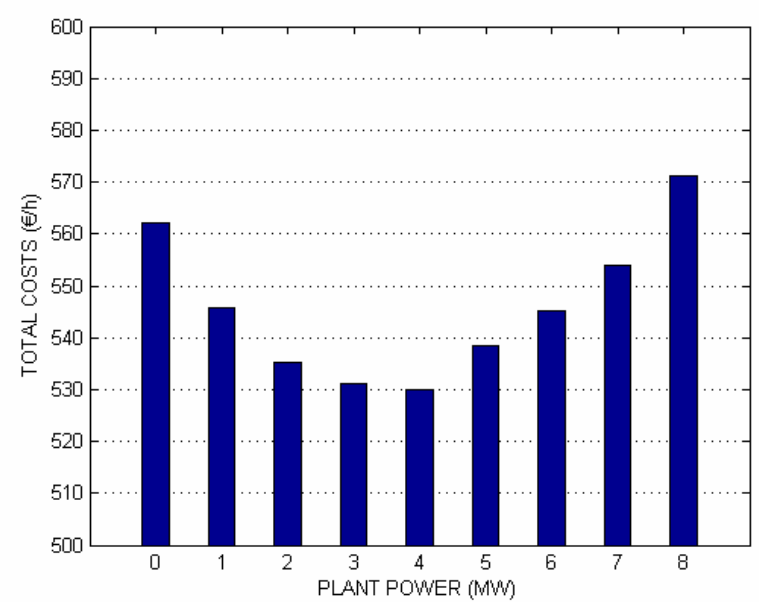

Fig. 8. Total costs. Generation system located at the BUS 9. 


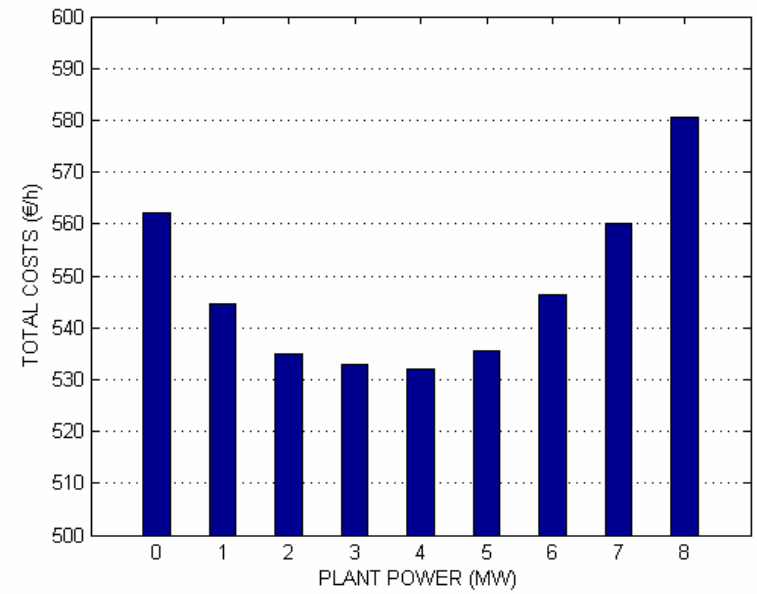

Fig. 9. Total costs. Generation system located at the BUS 10.

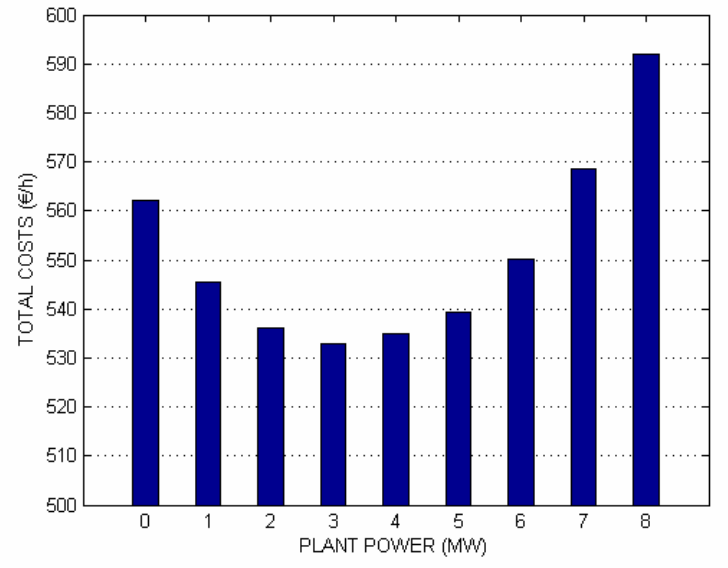

Fig. 10. Total costs. Generation system located at the BUS 11.

\section{Appendix}

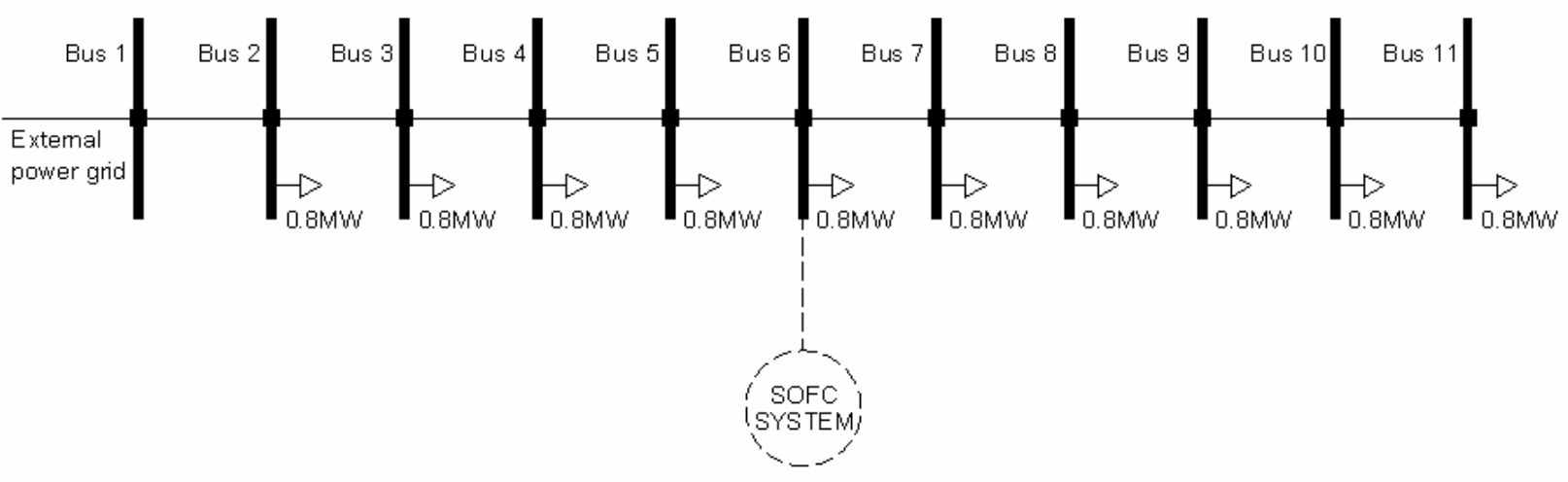

Fig. A1. Radial feeder considered.

TABLE A1. Parameters.

\begin{tabular}{|c|c|c|c|c|c|c|c|c|c|c|c|c|}
\hline Line Parameters & \multicolumn{6}{|c|}{$\begin{array}{l}\mathrm{R}=0.538 \Omega / \mathrm{km} \quad \mathrm{X}=0.4626 \Omega / \mathrm{km} \\
\text { Line length between two buses: } 2.5 \mathrm{~km}\end{array}$} & \multicolumn{5}{|c|}{$\begin{array}{l}\mathrm{R}=0.2152 \mathrm{pu} \quad \mathrm{X}=0.1850 \mathrm{pu} \\
\text { Bus Voltage }=25 \mathrm{kV}\end{array}$} & \multirow{2}{*}{$\begin{array}{c}\text { Total } \\
\text { Load } \\
(\mathrm{MW})\end{array}$} \\
\hline $\mathrm{N}^{\circ}$ bus & 1 & 2 & 3 & 4 & 5 & 6 & 7 & 8 & 9 & 10 & 11 & \\
\hline Load at each bus (MW) & 0.0 & 0.8 & 0.8 & 0.8 & 0.8 & 0.8 & 0.8 & 0.8 & 0.8 & 0.8 & 0.8 & 8.0 \\
\hline
\end{tabular}




\section{Conclusion}

This paper has presented a method to determine the optimal size and location of SOFC hybrid systems. These systems using forest residues as fuel in distribution systems. The aim is to minimize the energy losses and purchased energy cost from the point of the view of the electric distribution company and maximize the profitability from the investor's standpoint. The method is useful for any generation system that uses forest residues.

\section{References}

[1] Instituto para la Diversificación y Ahorro de la Energía, IDAE, Ministerio de Industria, Turismo y Comercio (Government of Spain), Plan de Energías Renovables en España 2005-2010, Aug. 2005. In Spanish.

[2] Directive 2001/77/EC of the European Parliament and of the Council on the promotion of electricity produced from renewable energy sources in the internal electricity market, Sep. 2001.

[3] F. Jurado and A. Cano, "Optimal placement of biomass fuelled gas turbines for reduced losses", Energy Conversion and Management, Vol. 47, No. 15-16, pp. 2673-2681, Dec. 2006.

[4] P. Dondi, D. Bayoumi, C. Haederli, D. Julian and M. Suter, "Network integration of distributed power generation", Journal of Power Sources, Vol. 106, No. (1-2), pp. 1-9, Apr. 2002.

[5] P. P. Barker and R. W. de Mello, "Determining the impact of distributed generation on Power Systems: Part 1 - Radial Distribution Systems", Proc. IEEE Power Engineering Society Summer Meeting, vol. 3, Seattle, WA, Jul. 16-20, 2000, pp. $1645-1656$.

[6] P. Chiradeja and R. Ramakumar, "An approach to quantify the technical benefits of distributed generation", IEEE Transactions on Energy Conversion, Vol. 19, No. 4, pp. 764-773, Dec. 2004.

[7] Techno-economical assessment of the production and use of bio-fuels for heating and cooling applications in South Europe, Bio-South Project, CENER. Available: http://www.biosouth.com.
[8] B. Velázquez Martí, "Situación de los sistemas de aprovechamiento de los residuos forestales para su utilización energética, Ecosistemas", Revista Científica y Técnica de Ecología y Medio Ambiente, No. 1, 2006. In Spanish.

[9] R. Banerjee, "Comparison of options for distributed generation in India", Energy Policy, Vol. 34, No. 1, pp. 101-111, Jan. 2006.

[10] A.O. Omosun, A. Bauen, N.P. Brandon, C.S. Adjiman and D. Hart, "Modelling system efficiencies and costs of two biomassfuelled SOFC systems", Journal of Power Sources, Vol. 131, No. (1-2), pp. 96-106, May. 2004.

[11] M.W. Ellis, M. R. Von Spakovsky and D. J. Nelson, "Fuel cell systems: efficient, flexible energy conversion for the 21 st century", Proceedings of the IEEE, Vol. 89, No. 12, pp. 18081818, Dec. 2001.

[12] M.C. Williams, J.P. Strakey and S.C. Singhal, "U.S. distributed generation fuel cell program", Journal of Power Sources, Vol. 131, No. (1-2), pp. 79-85, May. 2004.

[13] P. Kuchonthara, S. Bhattacharya and A. Tsutsumi, "Energy recuperation in solid oxide fuel cell (SOFC) and gas turbine (GT) combined system", Journal of Power Sources, Vol. 117, No. (1-2), pp. 7-13, May. 2003.

[14] M. Fiala, G. Pellizzi, G. Riva, "A model for the optimal dimensioning of biomasa-fuelled electric power plants", J. Agric. Eng. Res., Vol. 67, No. 1, 1997, pp. 17-25, May. 1997.

[15] T. Griffin, K. Tomsovic and D. Secrest, A. Law, "Placement of dispersed generation systems for reduced losses", Proceedings of the $33^{\text {rd }}$ Hawaii International Conference on System Sciences, Maui, Hawaii, 2000.

[16] Ministerio de Economía (Government of Spain), Royal Decree 436/2004, dated March 12, Boletín Oficial del Estado, 2004. In Spanish.

[17] Ministerio de Industria y Comercio (Government of Spain), Royal Decree 809/2006, dated July 1, Boletín Oficial del Estado, 2006. In Spanish.

[18] Consejería de Innovación, Ciencia y Empresa (Junta of Andalusia, Spain). Order July 18/2005, dated August 23, Boletín Oficial de la Junta de Andalucía, 2005. In Spanish. 